YАK $343.2 / .7$

ББК 67.408

DOI 10.22394/1682-2358-2018-1-81-87

G.V. Vershitskaya, Candidate of Sciences (Law), Docent of the Administrative and Criminal Law Department, Povolzhsky Institute of Management named after P.A. Stolypin, Branch of the Russian Presidential Academy of National Economy and Public Administration

\section{LEGAL ASPECTS \\ OF NEW POTENTIALLY DANGEROUS SUBSTANCES ILLEGAL TRAFFICKING}

Legal issues related to new potentially dangerous psychoactive substances illegal trafficking are considered. The modern practice of applying the new legislation regarding the substances under consideration is analyzed. The problems of initiating criminal cases related to illegal trafficking in new potentially dangerous psychoactive substances are discussed.

Key words and word-combinations: drug trafficking, new potentially dangerous psychoactive substances, the register of new psychoactive substances.
Г.В. Вериицкая, кандидат юридиеских наук, дочент кафедрь административного и уголовного права Поволжского института управления имени П.А. Стольтина - филиала Российской академии народного хозяйства и государственной службь при Президенте РФ (email: vershickaya@yandex.ru)

\section{ПРАВОВЫЕ АСПЕКТЫ НЕЗАКОННОГО ОБОРОТА НОВЫХ ПОТЕНЦИААЬНО ОПАСНЫХ ПСИХОАКТИВНЫХ ВЕЩЕСТВ}

\footnotetext{
Аннотация. Рассматриваются правовые вопросы, связанные с незаконным оборотом новых потенциально опасных психоактивных веществ. Анализируется современная практика применения законодательства в отношении рассматриваемых веществ. Обсуждаются проблемы возбуждения уголовных дел, связанных с незаконным оборотом новых потенциально опасных психоактивных веществ.

Ключевые слова и словосочетания: незаконный оборот наркотиков, новые потенциально опасные психоактивные вещества, реестр новых психоактивных веществ.

B

Российской Федерации правовые основы противодействия незаконному обороту наркотических средств, психотропных веществ и их аналогов в целях охраны зАоровья гражАан и государственной безопасности устанавцивает Федерацьный закон от 8 января 1998 г. «О наркотических средствах и психотропных веществах» (Аамее - Ф3 № 3). Перечень преступиений в
} 
сфере незаконного оборота наркотиков содержится в Уголовном кодексе Российской Федерации (ст. 228-233). В Аанной категории преступлений специфическим предметом преступного посягательства явцяются наркотические средства, психотропные вещества или их аналоги, оборот которых контролируется на территории Российской Федераџии (списки 1-4) [1] .

В середине 2000-х годов на территории России в незаконном обороте ста$\Lambda и$ появмяться так называемые новые психоактивные вещества, которые не входици ни в один из списков контролируемых веществ. По сути это был дерзкий вызов мировой системе контроля наА наркотиками, поскомьку попытки запретить или ограничить оборот каких- ибо веществ привели к появлению новых препаратов, сходных по действию, но отличающихся по химическому строению, и, следовательно, совершенно мегальных.

Под психоактивными традиџионно понимаются вещества естественного или искусственного происхождения, употребкение которых оказывает влияние на центральную нервную систему человека. Новые психоактивные вещества часто называют "дизайнерскими наркотиками» (от английского «tо design» - проектировать, разрабатывать), так как они разрабатываются с целью обхода установленных действующим законодательством запретов и ограничений. В соответствии со свойствами вешеств, действие которых они воспроизводят, новые психоактивные вещества (НПВ) делятся на синтетические каннабиноиды (например, «спайсы»); синтетические психостимуляторы (например, мефеАрон или «соли»); синтетические гамююиногены (например, кетамин) и Аругие.

С появлением новых видов психоактивных веществ кардинально поменялись и технологии их распространения. Основной площадкой их продажи стал Интернет, так называемая «теневая сеть» веб-наркорынков (например, Silk Road и Agora). Борьба с немегальными веб-рынками приводила к тем же результатам, что и борьба с самими наркотиками: закрытие одного ресурса приводицо к появлению гораздо больших по объему веб-наркорынков. Распространение на нелегальном рынке новых потенциально опасных психоактивных веществ привело к серьезным проблемам как для правоохранителей, так и для системы зАравоохранения. В связи с запретом одних веществ появмялось еще большее количество новых, информация о которых практически отсутствовала, что повышало риски их употребления.

Как известно, основанием дяя возбуждения уголовных дел в соответствии с ч. 2 ст. 140 УПК РФ явмяется «наличие достаточных данных, указывающих на признаки преступления» [2]. Аля уголовных дел, связанных с незаконным оборотом наркотиков, такими данными явмяется факт обнаружения и изъятия наркотических средств, психотропных веществ ици их аналогов у конкретного миџа. ОАна из особенностей возбуждения уголовных дел в сфере незаконного оборота наркотиков связана с получением данных, указывающих на признаки преступления, в ходе проведения оперативно-розыскных мероприятий.

Сформировавшаяся практика проведения, фиксаџии и уголовно-проџессуальной реализаџии результатов оперативно-розыскной деятельности (например, проверочной закупки наркотиков) несет в себе рял нарушений действу-

82 Bulletin of the Volga Region Institute of Administration • 2018. Vol. 18. № 1 
ющего законодательства, которые приводят к необоснованному возбуждению уголовных дел, их закрытию на стадии предварительного следствия из-за отсутствия достоверных и Аопустимых доказательств или к изменению квацификации преступления в сфере незаконного оборота наркотиков при рассмотрении уголовных дем в суде [3] .

Во избежкание случаев необоснованного возбуждения уголовных дел в ходе проверки оперативной информации о незаконных действиях с наркотиками необходимо установить следующее: относятся $\Lambda и$ изъятые вещества и препараты к наркотическим средствам, психотропным веществам или их аналогам; явцяются $\Lambda и$ действия с ними незаконными; какова масса изъятых веществ и препаратов.

Что касается новых психоактивных веществ, то стадия возбуждения угомовных дел по фактам их незаконного оборота имеет более значительный круг вопросов, требующих своевременного решения. Прежде всего это установмение мер правового контроця оборота указанных веществ. Первые запреты НПВ начались в конце 2000-х годов. Так, в 2008 г. в Израиле и вскоре в Швеции был запрещен мефедрон, который широко распространился к тому времени на нелегальном рынке Европейского союза [4]. В Великобритании с 2011 г. Аействует Реестр НПВ, предполагающий временный запрет на новые вещества и санкции за их производство и сбыт. В течение года должно быть произведено исследование вещества, на основании результатов которого выносится решение о его постоянном запрете ици кегальном регулировании. Правительство Австрации пошло по Аругому пути и наложило запрет на вещества исходя из их химической структуры, что слелало запрещенными многие вещества еще до их синтеза и появления на нелегальном рынке.

Теоретически контроль наА оборотом психоактивных веществ реализуется от тотацьного запрета до нерегуцируемой мегальной продажи. В мировой практике это, как правило, полностью бесконтрольная продажа пока еще не запрещенных веществ $и$ зо запрет с угрозой уголовной ответственности за незаконные действия с этими веществами.

В Российской ФеАерации выходом из сложившейся ситуации стало принятие Федерального закона от 3 февраця 2015 г. «О внесении изменений в отАельные законодательные акты Российской Федерации» № 7-Ф3 (далее - Ф3 № 7). Этим Законом была вылелена еще одна категория контролируемых веществ, получивших название «новые потенциально опасные психоактивные вещества». Согласно ФЗ № 7 УК РФ Аополняется ст. 234-1, устанавливающей уголовную ответственность за незаконный оборот новых потенциально опасных психоактивных веществ. В соответствии с ФЗ № 7 изменения были внесены и в Федеральный закон «О наркотических средствах и психотропных веществах» от 8 января 1998 г. № 3-Ф3 (далее - Ф3 № 3). Под новыми потенциально опасными психоактивными веществами в соответствии с указанными изменениями понимаются вещества синтетического или естественного происхождения, вызывающие у человека состояние наркотического или иного токсического опьянения, опасное Аһя его жкизни и зАоровья и в отношении ко-

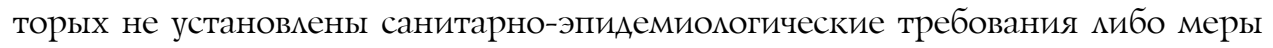


контроця за их оборотом [5]. За потребление данных вешеств предусматривается административная ответственность, причем миџо, употребляюшее такие вещества, обязано пройти медиџинское освидетельствование.

Кроме того, Ф3 № 3 дополняется ст. 2-2, согласно которой Федеральной службе по контролю наркотиков (Аалее - ФСКН) преАписывается формирование и ведение Реестра новых потенциально опасных психоактивных веществ. Предполагается, что в отношении каждого нового вещества в течение Авух иет Аолжно быть принято решение об установлении санитарно-эпидемиологических требований или мер контромя его оборота (отнесение к одному из списков согласно ФЗ № 3). Искмючение вещества из Реестра возможно по решению суда. Но 5 апремя 2016 г. Указом Президента РФ № 156 «О совершенствовании государственного управления в сфере контроля за оборотом наркотических средств, психотропных веществ и их прекурсоров и в сфере миграции» ФСКН была упразднена, ее функщии и полномочия переданы Министерству внутренних дел Российской Федерации [6] .

К этому времени в Реестре новых потенциально опасных психоактивных веществ не было ни одного вещества, что породимо рял правовых проблем, связанных с их незаконным оборотом, которые в настоящее время активно обсуждаются в спеџиальной митературе. В частности, анализируются признаки НПВ как элемента состава преступления [7], рассматриваются правовые и организаџионные аспекты противодействия обороту НПВ [8] и вопросы правового регулирования их оборота [9].

По нашему мнению, основная правовая проблема, во-первых, связана с отсутствием веществ в Реестре, что делает ст. 234-1 УК РФ не работающей.

Во-вторых, в соответствии с изменениями действующего законодательства новые потенциально опасные психоактивные вещества вносятся в Реестр и содержатся в нем в течение двух мет. По результатам экспертного исследования в отношении каждого вещества из Реестра устанавливаются санитарно-эпидемиологические требования мибо меры контроля (то есть вещество переносится в один из четырех списков контролируемых веществ в соответствии с Ф3 № 3). Но в новом законодательстве не определена процедура установления в отношении новых психоактивных веществ санитарно-эпидемиологических требований мибо мер контромя. Не понятно также, какое ведомство будет оџенивать опасность вешества в течение двух иет нахождения его в Реестре. Очевидно, что это должно быть Министерство зАравоохранения РФ, которое будет проводить клинические испытания новых веществ, определяя их химическую структуру и степень токсичности или безопасности Аля организма человека. При этом специалистами Министерства здравоохранения РФ Аолжны использоваться научно обоснованные универсальные методики экспертных исследований, поскольку объем новых психоактивных веществ неуклонно увемичивается. Такие методики пока не существуют.

Нерешенным остается также вопрос о том, каким образом новое вешество будет выводиться на мегальный рынок в случае определения его безопасности в ходе экспертных исследований. В соответствии с новым законодательством в отношении таких вешеств домжны быть разработаны санитарно-эпидемиоло- 
гические требования и другие меры мегального регулирования. Какое именно ведомство будет этим заниматься? В законе нет ответа на этот вопрос. Тем не менее факт отнесения нового вещества к одному из списков контроцируемых веществ или к новым потенциально опасным психоактивным веществам играет существенную роль с точки зрения уголовной ответственности за их незаконный оборот, то есть в новых нормах просматривается возможность ухода от более жесткого наказания.

В-третьих, Аля отнесения вещества к категории новых потенциально опасных психоактивных веществ необходимо наличие сощиальных, юридических и медиџинских признаков. Соџиальные признаки заключаются в том, что Аанные вещества синтезированы впервые и ранее не использовались Аля употребмения в целях опьянения, и что в результате их приема наступают опасные Аля жкизни и зАоровья последствия. Юридический признак заключается в том, что конкретное вещество признается новым потенциацьно опасным психоактивным веществом толыко после вкцючения его в Реестр, если в отношении него не установлены санитарно-эпидемиологические требования кибо меры контроця над его оборотом. Именно при наличии Аанного признака за незаконные действия с указанными веществами наступает уголовная мибо административная ответственность. Наконец, к медицинским признакам относятся факты потребления конкретного вешества, подтвержденные результатами меАиџинского освидетельствования миџ, находящихся поА его воздействием. К сожалению, законодатель не определяет количество таких миџ и симптоматику медицинских случаев. Кроме того, медицинское освидетельствование, предусмотренное ст. 44 Федерального закона «О наркотических средствах и психотропных вешествах» носит добровольный характер, в связи с чем конкретный потребитель вряА $и$ Аобровольно согласится на прохождение меАиЦинского освидетельствования. Считаем, что Аолжны быть четко обозначены медицинские критерии, согласно которым вещество можкет быть признано новым потенциально опасным психоактивным веществом. Это позволит избежать необоснованного расширения Реестра. Необходимо также внести изменения в действующее законодательство, позволяющее правоохранительным органом проводить меАиџинское освидетельствование Аиџ, находящихся в состоянии токсического или наркотического опьянения, в принудительном порядке.

По нашему мнению, дмя отнесения вещества к категории новых потенциально опасных психоактивных веществ необходимо учитывать и химические признаки новых веществ, поскольку они синтезируются с целью воспроизведения физиологического воздействия на организм человека наркотических среАств и психотропных веществ или их аналогов, оборот которых контролируется действующим законодательством.

В-четвертых, с введением изменений в действующее законодательство обозначились противоречия межАу понятиями «производные наркотических среАств и психотропных веществ», «аналоги наркотических среАств и психотропных веществ» и «новые потенциально опасные психоактивные вещества». Эти противоречия, как представцяется, связаны с отсутствием в действующем законодательстве четкого определения понятия производных наркотических 
средств и психотропных веществ. Содержкание понятия «новые потенциально опасные психоактивные вещества» рассмотрены ранее.

Аналогами наркотических средств и психотропных веществ в соответствии с ФЗ № 3 считаются запрещенные Аля оборота в Российской ФеАерации вещества синтетического или естественного происхождения, не включенные в Перечень наркотических среАств, психотропных веществ или их прекурсоров, подлежащих контролю в Российской Федераџии, химическая структура и свойства которых сходны с химической структурой и со свойствами наркотических среАств и психотропных веществ, психоактивное действие которых они воспрОИЗвоАят [1] .

Термин «производные наркотических среАств и психотропных веществ» впервые появияся в Перечне наркотических средств, утвержденном постановлением Правительства РФ от 30 июня 1998 г. № 681, в позиџиях «Экгонин и его производные» и «Аизергиновая кислота и ее производные» [10] . С 2010 г. Перечень наркотических среАств и психотропных веществ начаА пополняться «Производными», когда в него стали вкцючать психоактивные компоненты курительных смесей и «Аизайнерские» наркотики. В постановлении Правительства РФ от 19 ноября 2012 г. № 1178 было дано, на наш взгляд, невнятное определение понятия «производные наркотических средств и сильнодействующих веществ». "Производные» опреАелялись как вещества синтетического или естественного происхождения, которые не вкАючены самостоятельными позициями в государственный реестр мекарственных среАств или в настоящий перечень, химическая структура которых образована заменой одного ици нескольких атомов водорода, галогенов и (ици) гидроксицьных групп в химической структуре соответствующего наркотического средства или психотропного вещества на иные одновалентные и (или) двухвацентные атомы или заместители (за искиючением гидроксицьной и карбоксильной групп), суммарное количество атомов углерода в которых не Аолжно превышать количество атомов углерода в исходной химической структуре соответствующего наркотического средства или психотропного вешества [11]. Аанное определение, по нашему мнению, перекиикается с определением аналогов наркотических среАств и психотропных веществ в части, касающейся их химической структуры, но не учитывает характер их воздействия на организм человека. В связи с этим считаем, что существующее определение понятия «производные наркотических среАств и психотропных веществ» нельзя использовать дия решения вопроса об отнесении нового вешества к той или иной категории контролируемых веществ. Правоохранительные органы, как правило, решают этот вопрос по своему усмотрению, что в большинстве случаев приводит к коррупционным проявмениям и правовому шантажу.

Таким образом, внесение изменений и дополнений в действующее законоАательство частично решило проблему незаконного оборота новых потенциально опасных психоактивных веществ, выделив их в отдельную категорию. Но вопросы, касающиеся исследования указанных веществ и проџедуры отне-

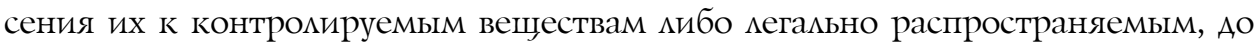


сих пор остаются нерешенными, что может привести к правовым коммизиям в вопросах правоприменения нового законодательства.

\section{Библиографический список}

1. О наркотических средствах и психотропных веществах: Федер. закон от 8 янв.1998 г. № 3-Ф3 [Электронный ресурс]. Доступ из СПС «КонсультантПлюс».

2. Уголовно-процессуальный кодекс Российской Федерации от 18 дек. 2001 г. № 174-ФЗ (в ред. от 3 февр. 2014 г. с изм., вступил в силу 15 февр. 2014 г.) [Электронный ресурс]. Доступ из СПС «КонсультантПлюс».

3. Вершицкая Г.В. Использование проверочной закупки наркотиков для целей розыска и доказывания // Вестник Поволжской академии государственной службы. 2013. № 2. С. 67-73.

4. Вершиџкая Г.В., Рыбалов В.С. Возможности экспертного исследования смесей, содержащих наркотическое средство мефедрон // Судебный эксперт. 2012. № 2. С. 93-101.

5. О внесении изменений в отдельные законодательные акты Российской Федерации: Федер. закон от 3 февр. 2015 г. № 7-Ф3 (в ред. от 3 июля 2016 г.) [Электронный ресурс]. Доступ из СПС «КонсультантПлюс».

6. О совершенствовании государственного управления в сфере контроля за оборотом наркотических средств, психотропных веществ и их прекурсоров и в сфере миграции: Указ Президента РФ от 5 апр. 2016 г. № 156 (в ред. от 21 дек. 2016 г.) [Электронный ресурс]. Доступ из СПС «КонсультантПлюс».

7. Артюшина О.В., Усманова Н.М. Объект незаконного оборота новых потенциально опасных психоактивных веществ // Вестник Казанского юридического института МВД России. 2016.

8. Свистильников А.Б., Новоселов Н.Г., Моисеев Н.А. Теоретические и прикладные аспекты противодействия преступности органами внутренних дел // Проблемы правоохранительной деятельности. 2015.

9. Бычкова А.М. Новые потенциально опасные психоактивные вещества: неадекватность правового реагирования на вызовы наркорынка // Известия Байкальского государственного университета. 2016.

10. Об утверждении перечня наркотических средств и психотропных веществ и их прекурсоров, подлежащих контролю в Российской Федерации: постановление Правительства РФ от 30 июня 1998 г. № 681 (с изм. и доп.) [Электронный ресурс]. Доступ из СПС «КонсультантПлюс».

11. О внесении изменения в перечень наркотических средств, психотропных веществ, подлежащих контролю в Российской Федерации: постановление Правительства РФ от 19 нояб. 2012 г. № 1178 [Электронный ресурс]. Доступ из СПС «КонсультантПлюс». 